\title{
Upregulation of Fibronectin Synthesis by Interleukin-1 $\beta$ in Coronary Artery Smooth Muscle Cells Is Associated with the Development of the Post-Cardiac Transplant Arteriopathy in Piglets
}

\author{
Nadine Clausell and Marlene Rabinovitch \\ Division of Cardiovascular Research, Research Institute, The Hospital for Sick Children, and Departments of Pathology and Pediatrics, \\ University of Toronto, Toronto, Ontario M5G 1 X8, Canada
}

\begin{abstract}
We previously described in piglets after heterotopic cardiac transplantation the early development of a coronary arteriopathy characterized by increased immunostaining for fibronectin and interleukin-1 $\beta$ (IL-1 $\beta$ ) in the vessel wall. The objective of this study was to culture smooth muscle cells from donor and host coronary arteries in these piglets to determine whether donor cells produce more fibronectin than host cells as judged by increased protein and mRNA levels, and whether IL-1 $\beta$ may be regulating this increase by an autocrine mechanism involving increased production of the cytokine. We documented increased donor coronary artery smooth muscle cell fibronectin protein synthesis and mRNA compared to host. By using neutralizing antibodies to IL-1 $\beta$, fibronectin protein synthesis and mRNA levels were reduced in donor cells to the levels observed in the host cells and a similar reduction in synthesis was observed with the IL-1 receptor antagonist. Immunoprecipitation of newly synthesized IL-1 $\beta$ revealed increased endogenous levels in donor compared to host cells. We therefore suggest in the coronary arteriopathy a pathophysiologic mechanism whereby IL-1 $\beta$-mediated increased fibronectin synthesis may promote lymphocyte trapping and migration of medial smooth muscle cells leading to progressive intimal thickening associated with the post-cardiac transplant coronary arteriopathy. (J. Clin. Invest. 1993. 92:1850-1858.) Key words: cardiac allograft • cytokines • extracellular matrix • graft atherosclerosis • vascular smooth muscle cell phenotype
\end{abstract}

\section{Introduction}

The development of an obstructive coronary arteriopathy is a major cause of morbidity and mortality in cardiac transplant recipients $(1,2)$ accounting for $36 \%$ of the deaths in patients who survive beyond $1 \mathrm{yr}$ after transplantation (3). The most widely accepted current thinking regarding the pathogenesis of

This study was presented in part at the 65th Annual American Heart Association Scientific Sessions in New Orleans, LA, November 1992, and has been published in abstract form (1992. Circulation. 86:I-769).

Address reprint requests to Dr. Marlene Rabinovitch, Division of Cardiovascular Research, The Hospital for Sick Children, 555 University Avenue, Toronto, ON M5G 1X8, Canada.

Received for publication 3 November 1992 and in revised form 3 May 1993.

J. Clin. Invest.

(C) The American Society for Clinical Investigation, Inc. $0021-9738 / 93 / 10 / 1850 / 09 \$ \$ 2.00$

Volume 92, October 1993, 1850-1858 the post-cardiac transplant coronary arteriopathy (PCTCA) ${ }^{1}$ is that there is an ongoing immune-inflammatory reaction in the vessel wall with activation of endothelial cells expressing major histocompatibility complex (MHC) II antigens which stimulate lymphocyte proliferation and sustained release of cytokines. This could cause proliferation and migration of smooth muscle cells into the subendothelium and accumulation of extracellular matrix contributing to intimal thickening (4).

Others have shown an association between fibronectin ( 5 , 6 ) and glycosaminoglycan (GAG) (7) accumulation and intimal proliferation in atherosclerosis. Our previous studies addressing the mechanisms involved in the intimal proliferation that occurs in the ductus arteriosus have related increased smooth muscle cell fibronectin synthesis and increased endothelial cell hyaluronan synthesis to enhanced smooth muscle cell migration (8). Fibronectin is also involved in promoting adhesion of inflammatory cells to endothelial cells, transendothelial migration, and the positioning of these cells in the subendothelium (9-11), features associated with the immuneinflammatory reaction observed in the pathogenesis of graft atherosclerosis.

An increase in circulating levels and in tissue expression of cytokines after organ transplantation has been reported (12, 13). Although increased expression of IL-1 has not been described specifically in association with the PCTCA, it has been demonstrated experimentally in a murine cardiac allograft (14). Increased expression of IL-1 mRNA and protein has been found in the nonhuman atherosclerotic plaque (15), and, because of its numerous biological functions, this cytokine may play an important role in vascular pathology. For example, IL-1 regulates smooth muscle cell proliferation, stimulates leukocyte adherence to the endothelium, and induces GAG synthesis by fibroblasts (16-18). Also, it has been shown that smooth muscle cells, once induced by exogenous IL-1 or IL-6, maintain endogenous upregulation of these cytokines $(19,20)$.

TGF- $\beta$ is also an important modulator of the extracellular matrix, e.g., it increases fibronectin synthesis in different cell types $(21,22)$. Our previous studies have shown that the increase in GAG synthesis by endothelial cells detected in the ductus arteriosus associated with intimal thickening is TGF- $\beta$ dependent (23). A relationship between inflammatory cells, cytokines, and an increase in matrix proteins contributing to intimal thickening has been demonstrated by Navab et al.

1. Abbreviations used in this paper: CsA, cyclosporine A; GAG, glycosaminoglycan; GAPD, glyceraldehyde-3-phosphate dehydrogenase; PCTCA, post-cardiac transplant coronary arteriopathy; ra, receptor antagonist. 
(24). When aortic endothelial and smooth muscle cells were co-cultured with monocytes, increased fibronectin synthesis was observed and found to be partially dependent on IL-1 and IL-6 (24).

Although several animal species have been used to investigate the pathogenesis of PCTCA, there are distinct advantages in using piglets as an experimental model. The piglet most closely resembles the human in the development of atherosclerosis not induced by a high cholesterol diet (25), and the size and morphology of the arteries allow the harvesting of cells for in vitro experiments to address mechanisms involved in the pathogenesis of the PCTCA. Moreover, the pattern of allograft rejection involving $\mathrm{MHC}$ mismatching observed in humans is virtually identical to that in piglets $(26,27)$.

We previously described changes related to the development of the PCTCA in piglets after heterotopic cardiac transplantation. We demonstrated the presence of an immune-inflammatory reaction in the donor heart coronary arteries characterized by the infiltration of $\mathrm{T}$ cell subsets $\left(\mathrm{CD} 4^{+}, \mathrm{CD} 8^{+}\right.$, and $\mathrm{CD} 2^{+}$), granulocytes, and monocytes, in addition to the expression of MHC II molecules in the endothelium. We found a significant increase in accumulation of fibronectin in the donor coronary arteries associated with increased expression of IL- $1 \beta$. These findings did not appear to be related to the use of cyclosporine $\mathrm{A}$ ( CsA ), the duration of the experimental period, or the rejection grade (28). We speculated that the increased fibronectin accumulation was related to increased synthesis by vascular cells and was regulated by IL- $1 \beta$ in a paracrine or autocrine manner.

In this study we cultured smooth muscle cells from donor and host coronary arteries from piglets after heterotopic cardiac transplantation, characterized these cells according to their production of extracellular matrix, and were able for the first time to address specifically whether they maintained an altered phenotype associated with increased fibronectin synthesis and whether this abnormality was regulated by increased endogenous production of IL- $1 \beta$ or other cytokines, e.g., TGF$\beta$, IL- $1 \alpha$, and IL- 6 . We in fact documented increased fibronectin synthesis in smooth muscle cells from donor coronary arteries compared to host associated with increased mRNA levels for fibronectin. We were able to neutralize the increase in donor coronary artery fibronectin synthesis, but only with antibodies to IL- $1 \beta$ or the IL- 1 receptor antagonist. We further showed increased IL-1 $\beta$ synthesis by donor coronary artery smooth muscle cells. These in vitro observations are supported by our in vivo findings and suggest a mechanism whereby increased IL- $1 \beta$ upregulates smooth muscle cell fibronectin production by an autocrine mechanism. Increased fibronectin could contribute to transendothelial inflammatory cell migration and trapping in the subendothelium, as well as migration of smooth muscle cells from the media into the subendothelium, features observed in the pathophysiology of the PCTCA.

\section{Methods}

\section{Experimental animal preparation}

Outbred piglets between 8 and 12 wk of age weighing 20-30 kg underwent a heterotopic cardiac allograft. This involved retroperitoneal anastomoses of the donor ascending aorta and main pulmonary artery with the recipient abdominal aorta and inferior vena cava, respectively, keeping the native heart in the original position. This procedure required removal of one kidney to graft the donor heart in the retroperito- neal space. Further technical details of the surgery have previously been described (29). The animals were unselected to favor an HLA mismatch and both host and donor animals were purchased from different sources. Each donor heart received crystalloid cardioplegia before transplantation and the donor hearts were grafted within $15 \mathrm{~min}$ of cardioplegic arrest. The cardioplegic solution consisted of 5\% dextrose with $1.6 \mathrm{mM} \mathrm{Mg} \mathrm{SO}_{4}, 0.54 \mathrm{mM}$ tris (hydroxymethyl) amino methane, $29 \mathrm{mM} \mathrm{NaCl}$, and $21.4 \mathrm{mM} \mathrm{KCl}$ at pH 8.14 and osmolarity 351 . The animals received penicillin $\mathrm{G}(150,000 \mathrm{U}$ i.m. $)$ and standard postoperative care in compliance with the Principles of Laboratory Animal Care formulated by the Canadian National Society of Medical Research. The experimental protocol was approved by the Animal Care Committee of The Hospital for Sick Children, Toronto.

A total of 14 piglets were studied: 7 were treated with a subtherapeutic regimen of CsA (Sandimune, Sandoz, East Hanover, NJ) ( 10 $\mathrm{mg} / \mathrm{kg}$ per $\mathrm{d}$ for $5 \mathrm{~d}$ ) and the remaining 7 piglets received no immunosuppressive therapy. All piglets had electrocardiographic monitoring performed daily by telemetric assessment (Pacesetter System, Inc., Syalam, CA) to identify signs of progressive rejection as previously described (30). A decrease of $30 \%$ compared to baseline in the electrocardiographic voltage by $4 \mathrm{~d}$ and of $50 \%$ thereafter was the indication used to terminate the experiments. These indications were a reflection of myocardial rejection grades II and III. Based on these criteria, 7 CsA-treated piglets were followed for an experimental period of 4-31 d (median $10 \mathrm{~d}$ ) and the 7 non-CsA-treated piglets were followed for an experimental period of only 4-8 d (median $4 d$ ).

\section{Harvest of coronary artery tissue and propagation of smooth muscle cells}

Coronary artery segments, $\sim 1 \mathrm{~cm}$ from the origin at the aorta and 4 $\mathrm{cm}$ in length, were removed from both the host and the donor hearts and rinsed in Dulbecco's PBS with $3 \%$ antibiotics/antimycotics (Gibco, Burlington, ON). The most distal $1 \mathrm{~cm}$ of these segments was fixed for light and electron microscopy $(0.5 \mathrm{~cm}$, respectively) to analyze structural changes previously described $(28)$. The proximal $3 \mathrm{~cm}$ of coronary artery was used for harvest and culture of cells.

After removing the endothelium, explants from the media were used to propagate the smooth muscle cells (31) used in the present studies. The cells were cultivated in medium 199 with $25 \mathrm{mM}$ Hepes buffer, glutamine, and $1 \%$ antibiotics/antimycotics (Gibco) and $10 \%$ FBS (Intergen, New York). Cells were passaged 1:2 nonenzymatically into 25-ml flasks and all experiments were carried out using cells at passages 2 and 3 . The number of harvests (piglets) studied and the number of determinations made (flasks) are given in Results and in the figure legends.

\section{Characterization of the in vitro system}

Identification of cells. Only cells with the "hills and valleys" phenotype on phase contrast light microscopy (Nikon Diaphot, Nikon, Mississauga, $\mathrm{ON}$ ) were considered smooth muscle cells and were further positively identified by immunofluorescence using monoclonal antibodies specific to smooth muscle actin (Enzo, New York) (32). Virtually all cells stained positively as we have previously shown (33).

Growth curves. Briefly, $50 \times 10^{3}$ smooth muscle cells per well were plated in 24-well plates (Costar, Cambridge, MA). After $24 \mathrm{~h}$ and each $48 \mathrm{~h}$ thereafter, the cells were harvested with $0.05 \%$ trypsin and $0.02 \%$ EDTA (Gibco), resuspended in saline, and 100- $\mu$ l aliquots were counted in triplicate (model ZF, Coulter Electronics, Hialeah, FL).

Protein synthesis. The smooth muscle cells were radiolabeled with $\left[{ }^{35} \mathrm{~S}\right]$ methionine (Amersham, Oakville, ON) for $24 \mathrm{~h}$ in a serum-free condition. Then duplicate aliquots of medium ( $200 \mu \mathrm{l} \mathrm{each})$ were precipitated twice in 10\% TCA (Sigma Chemical Co., Saint Louis, MO) using BSA (Boehringer-Mannheim, Federal Republic of Germany) as a co-precipitant, and dried in ethanol under nitrogen (34). Pellets were solubilized in Protosol (DuPont-New England Nuclear, Boston, MA) at $50^{\circ} \mathrm{C}$ for $45 \mathrm{~min}$ and counted in scintillation fluid (ACS) (Amersham) at $\mathrm{pH} 6.5$. 


\section{Synthesis of GAGs and fibronectin}

\section{BIOSYNTHETIC LABELING OF CELLS}

To determine synthesis of GAGs, i.e., hyaluronan, heparan sulfate, and chondroitin sulfate, $10 \mu \mathrm{Ci} / \mathrm{ml}\left[{ }^{3} \mathrm{H}\right]$ glucosamine (Amersham) was used to label the cells for $48 \mathrm{~h}$ in the presence of medium $199+10 \%$ FBS. To determine synthesis of fibronectin, confluent smooth muscle cells had culture medium replaced with medium 199 without FBS (serum-free) to which $10 \mu \mathrm{Ci} / \mathrm{ml}$ of $\left[{ }^{35} \mathrm{~S}\right]$ methionine (Amersham) was added for $24 \mathrm{~h}$. We did not use methionine-free medium, as in our previous studies (23). Smooth muscle cells from host and donor coronary arteries were always assayed at the same time.

\section{PREPARATION OF MEDIUM, CELL LAYERS, AND MATRICES}

The culture medium was removed and saved in the presence of protease inhibitors ( 2 mM PMSF (Eastman Kodak Co., Rochester, NY), $10 \mathrm{mM} N$-ethylmaleamide, and $10 \mathrm{mM}$ EDTA (Sigma). The cell layers were extracted with hypotonic buffer followed by rinsing in $0.5 \%$ NP40 (Sigma) (35), and the matrices remaining in the flasks were removed after an overnight incubation at $4^{\circ} \mathrm{C}$ with $2 \mathrm{M}$ guanidine (Sigma). The cell lysates and matrices were stored at $-70^{\circ} \mathrm{C}$.

\section{ANALYSIS OF GAGs}

Soluble GAG fractions from smooth muscle culture medium, were precipitated according to the method used by Copp and Bernfield (36) and the final GAG precipitates were resuspended in water. The final separation of hyaluronan, heparan sulfate, and chondroitin sulfate was performed using an HPLC system (Waters, Milford, MA) with a TSK 3SW DEAE column ( $15 \times 15$, Beckman Instruments, Inc., Palo Alto, CA) with a three-step $\mathrm{NaCl}$ gradient from 0.05 to $0.75 \mathrm{M}$ (37). Fractions were collected every 2 min and radioactivity was determined by liquid scintillation spectrometry. Individual peaks were confirmed by their susceptibility to heparinitase (Sigma), chondroitinase ABC (Sigma), and streptomyces hyaluronidase (Calbiochem Corp., La Jolla, CA).

\section{EXTRACTION OF FIBRONECTIN}

To extract fibronectin, 400- $\mu$ l aliquots of medium and cells were applied to a Gelatin 4B-Sepharose (Pharmacia, Uppsala, Sweden ) microcolumn ( 38 ). The fibronectin retained was eluted by boiling the samples for $3 \mathrm{~min}$ in $200 \mu \mathrm{l}$ of SDS sample buffer and resolved on 5\% SDS-PAGE under reducing conditions. The gels were prepared for autoradiography for quantitative analysis by treatment with $\mathrm{En}^{3} \mathrm{Hance}$ (DuPont-New England Nuclear) for $2 \mathrm{~h}$ and dried on a model $443 \mathrm{slab}$ dryer (Bio-Rad Laboratories, Richmond, CA) and exposed to Kodak $\mathrm{X}$-OMAT AR-5 film for $3 \mathrm{~d}$ at $-70^{\circ} \mathrm{C}$. Using the autoradiograph as a template, the doublet $220 \mathrm{kD}$ band corresponding to fibronectin was cut and radioactivity was determined by liquid scintillation spectrometry. Positive determination of this band as fibronectin was confirmed by Western immunoblot.

Screening for candidate cytokines that regulate fibronectin synthesis. In confluent smooth muscle cells from the host and donor coronary arteries, the medium was replaced by serum-free medium $(2 \mathrm{ml})$, and the cells were labeled with $\left[{ }^{35} \mathrm{~S}\right]$ methionine $(10 \mu \mathrm{Ci} / \mathrm{ml})$ and incubated at $37^{\circ} \mathrm{C}$ for $24 \mathrm{~h}$ with neutralizing antibodies, i.e., rabbit antiTGF- $\beta$ from porcine platelets ( AB-10-NA, R \& D Systems, Minneapolis, $\mathrm{MN})(10 \mu \mathrm{l} / \mathrm{ml})$ or rabbit anti-porcine IL- $1 \alpha$, or IL- $1 \beta$ (a gift from Dr. Saklatvala, Strangeways Laboratory, Cambridge, England and used in a 1:10,000 and 1:50 dilution, respectively), and rabbit anti-human IL-6 (Genzyme, Boston, MA) used in a 1:50 dilution $(20 \mu \mathrm{g} / \mathrm{ml})$. All the experiments were controlled by using rabbit IgG (Dako Corp., Santa Barbara, CA) in similar concentration to that of the antibody used. Fibronectin and total protein synthesis were measured as described above.

\section{DNA STANDARDIZATION}

All values related to synthesis were standardized by determining, in triplicate, DNA content from $400-\mu$ l aliquot cell suspensions. Measure- ment of DNA binding to the fluorescent dye, bisbenzamide (Hoechst Reagent $\mathrm{H}$ 3313, Calbiochem), was carried out as previously described (39). Results are expressed as cpm/100 ng DNA.

\section{ASSESSMENT OF FIBRONECTIN MRNA}

Extraction of RNA. Smooth muscle cells were grown to confluence in $\mathrm{T}-25 \mathrm{ml}$ flasks and the culture medium was changed to serum-free medium for $24 \mathrm{~h}$ and RNA was extracted according to the single-step acid guanidinium thiocyanate-phenol-chloroform method used by Chomczynski and Sacchi (40). A purified 1.5-kb human fibronectin cDNA purchased from Telios Pharmaceuticals (La Jolla, CA) was labeled with $\left[{ }^{32} \mathrm{P}\right] \mathrm{dCTP}$ using a random primer kit (Amersham) and probes with specific activities of $>10^{9} \mathrm{cpm} / \mu \mathrm{g}$ were recovered after Sephadex G-50 column chromatography. Prehybridizations and hybridizations were performed for $24 \mathrm{~h}$ at $42^{\circ} \mathrm{C}$ using standard techniques. The stringency conditions for washing involved alternating 2 $\times$ SSC with $0.1 \mathrm{SSC}$ with $0.1 \%$ SDS added to both, at $50^{\circ} \mathrm{C}$ from a total of $2.5 \mathrm{~h}$. Stock SSC $(20 \times)$ is made up by adding $\mathrm{NaCl} 701 \mathrm{~g}$ to $\mathrm{Na}$ citrate $352 \mathrm{~g}$ in 4 liters of diethyl pyrocarbonate water. Autoradiographs of RNA blot hybridizations were analyzed by quantitative densitometry (Bio-Rad model 620) of appropriately exposed film (Kodak X-OMAT AR5). Values were standardized by densitometry to mRNA levels of a "housekeeping" gene, glyceraldehyde-3-phosphate dehydrogenase (GAPD), and also to $18 \mathrm{~s}$ and $28 \mathrm{~s}$ ribosomal RNA assessed from the ethidium bromide stained gels to correct for any differences in total RNA loaded onto the gels. A 1.2-kb cDNA probe for GAPD was purchased from ATCC (Rockville, MD) and isolated from pBR322 by Pst 1 digestion.

We also measured fibronectin mRNA levels after incubation of smooth muscle cells with neutralizing IL-1 $\beta$ antisera (dilution 1:50). For these experiments, fibronectin mRNA levels were determined at $12 \mathrm{~h}$ after a preliminary time-course assessment which indicated that this was a reliable time point. Rabbit IgG was used as a control.

\section{Immunoprecipitation of newly synthesized IL-1 $\beta$ by smooth muscle cells}

Measurement of IL- $1 \beta$ synthesized by both host and donor coronary artery smooth muscle cells was performed by immunoprecipitation after incubation of confluent cells with $\left.100 \mu \mathrm{Ci} / \mathrm{ml} \mathrm{[}{ }^{35} \mathrm{~S}\right]$ methionine for $24 \mathrm{~h}$ in serum-free medium. Medium was saved with protease inhibitors and cells were lysed using $1 \times$ lysis buffer $(50 \mathrm{mM}$ Tris- $\mathrm{Cl} \mathrm{pH} 7.5$, $150 \mathrm{mM} \mathrm{NaCl}, 1 \% \mathrm{NP}-40$ [Sigma], $0.5 \%$ sodium deoxycholate [Sigma], $0.1 \% \mathrm{SDS}$ ). Aliquots of $1 \mathrm{ml}$ of cell lysates were then incubated with nonimmune rabbit IgG ( 0.05 volumes) (Dako Corp.) for 4 $\mathrm{h}$ at $4^{\circ} \mathrm{C}$ followed by clearing with $100 \mu \mathrm{l}$ of Protein A agarose (Sigma) for $1 \mathrm{~h}$. The samples were centrifuged at $10,000 \mathrm{~g}$ for $5 \mathrm{~min}$ and the supernatant incubated with anti-IL-1 $\beta$ antibodies in a 1:100 dilution for $24 \mathrm{~h}$ at $4^{\circ} \mathrm{C}$. Another $100 \mu \mathrm{l}$ of Protein A agarose was added for $1 \mathrm{~h}$. The samples were then washed four times with RIPA buffer and the final pellet was resuspended in $50 \mu \mathrm{l}$ of SDS sample buffer and heated for $10 \mathrm{~min}$ before loading in a $12.5 \%$ SDS-PAGE. The gels were prepared for autoradiography as described above. Bands appearing at $\sim 30 \mathrm{kD}$ corresponding to the precursors of IL- $1 \beta$ were cut and analyzed by liquid scintillation spectrometry as described above. Results were expressed as cpm/100 ng DNA.

\section{Statistical analysis}

Data are expressed as mean $\pm \mathrm{SE}$ in Results and in the figure legends. In analyses related to cell growth, protein, and GAG synthesis, the Student $t$ test was used to compare host and donor cells. We also used the Student $t$ test to determine whether there was an increase in fibronectin synthesis in response to higher doses of IL- $1 \beta$ when compared with control values and lower doses. Since not all harvests showed a greater than twofold increase in donor versus host fibronectin synthesis, we used the Fisher's exact test to assess whether this variability might be related to the duration of transplant in the CsA-treated and non-CsAtreated piglets. In all analyses a $P<0.05$ was considered significant. In 
all other experiments, values in the donor are expressed as a percentage of those in the host.

\section{Results}

Growth and protein synthesis. We first determined whether there were differences between donor and host coronary artery smooth muscle cells related to growth. Comparing host and donor coronary artery smooth muscle cells harvested from three different piglets-one non-CsA-treated at $7 \mathrm{~d}$ after cardiac transplantation and two CsA-treated piglets at 7 and $8 \mathrm{~d}$ after transplantation, we observed no significant differences in the rate of growth (Fig. 1) or protein synthesis. The latter was assessed by measuring methionine-labeled proteins recovered in the cell culture medium (host values $7,727 \mathrm{cpm} / 100 \mathrm{ng}$ $\mathrm{DNA} \pm 3,186 \mathrm{SE}$; donor values $8,653 \mathrm{cpm} / 100 \mathrm{ng} \mathrm{DNA} \pm 4,156 \mathrm{SE}$ ).

Synthesis of GAGs. Production of extracellular matrix GAGs in host and donor coronary artery smooth muscle cells from the above harvests were not significantly different with respect to synthesis of hyaluronan, heparan sulfate, or chondroitin sulfate (Fig. 2). The increase in donor coronary artery smooth muscle cell heparan sulfate was not statistically significant $(P=0.144)$, and is based upon a high donor value in only one the three animals studied.

Synthesis of fibronectin. There was, however, an increase in donor smooth muscle cell fibronectin synthesis compared to that of host in these initial harvests. We therefore extended our analyses to include cells from 14 different piglets: 7 non-CsAtreated piglets at 4-8 d after cardiac transplantation and $7 \mathrm{CsA}$ treated piglets at 7-31 d after transplantation. In five of seven harvests obtained from non-CsA-treated piglets at $4 \mathrm{~d}$ or CsAtreated animals at 7-8 d after cardiac transplantation, there was either no or only a modest $(<150 \%)$ increase in fibronectin synthesis in donor compared to host coronary artery smooth muscle cells, whereas in six of seven harvests from non-CsA-treated piglets at 7-8 d or CsA-treated piglets at 10 $31 \mathrm{~d}$ after cardiac transplantation, a $200-800 \%$ increase in fibronectin synthesis was observed $(P<0.05)$ (Fig. 3$)$. These data suggest that the increase in fibronectin synthesis is expressed

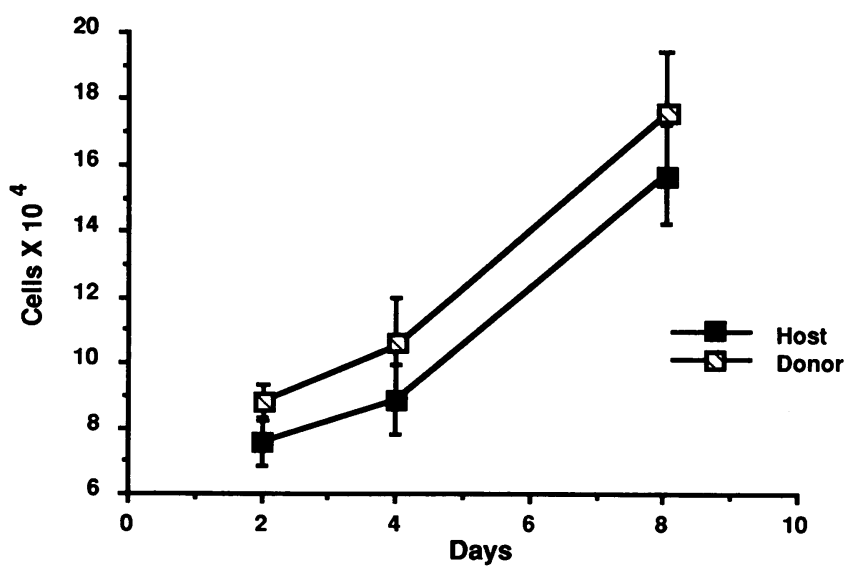

Figure 1 . Host and donor coronary artery smooth muscle cell growth rates. Assessment of characteristics of cell growth at days 2, 4, and 8 after seeding reveals similar values for host and donor cells. Values are mean \pm SE, calculated based upon the average value of duplicate flasks from cells of three different piglets.

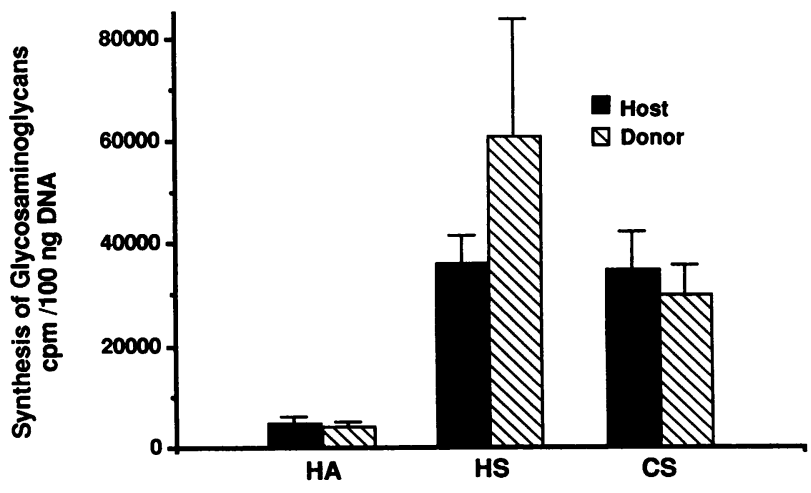

Figure 2. Synthesis of GAGs recovered from culture medium from host and donor coronary artery smooth muscle cells. After labeling the cells with $\left[{ }^{3} \mathrm{H}\right]$ glucosamine and separating the GAG fractions using an HPLC system with a $\mathrm{NaCl}$ gradient, similar values of hyaluronan $(H A)$, chondroitin sulfate $(C S)$, and heparan sulfate $(H S)(P$ $=0.144)$ are observed. Values are expressed in cpm/100 ng DNA and are mean $\pm \mathrm{SE}$, based on the average values of duplicate flasks from cells from three different piglets.

earlier in cultured donor coronary artery smooth muscle cells from non-CsA-treated animals. They also may suggest that a certain duration of expression in vivo is required before the cultured cells will maintain this property in vitro. There was no significant difference $(P=0.27)$ in relative values comparing the two groups with higher donor fibronectin synthesis, i.e., the non-CsA group at 7-8 d after cardiac transplantation and the CsA treated group at 10-31 d.

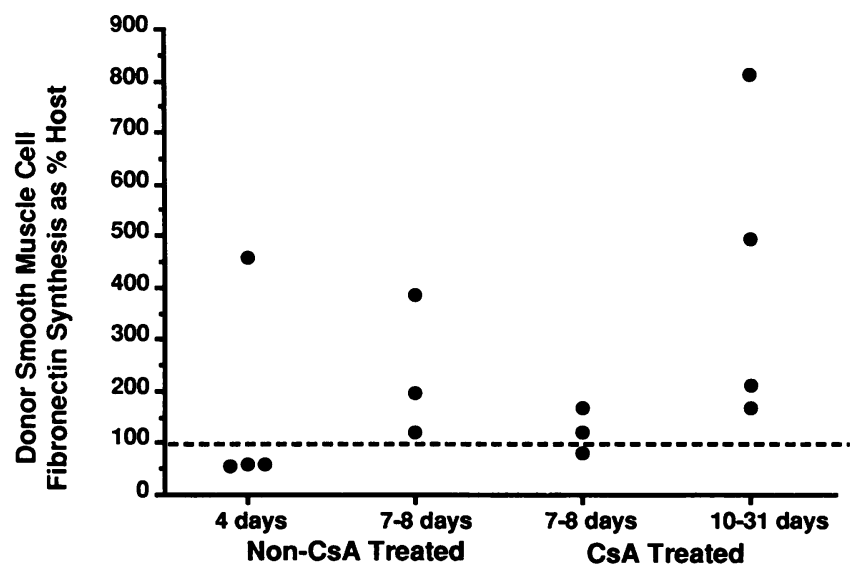

Figure 3. Synthesis of fibronectin in donor coronary artery smooth muscle cells expressed as a percentage of that in host coronary artery smooth muscle cells. Values are expressed as individual points for each time point studied, based on average values from duplicate flasks for each cell harvest. Cells were harvested when electrocardiographic criteria indicated that there was graft rejection as described in the text, i.e., a decrease of $40 \%$ compared to baseline voltage at $4 \mathrm{~d}$ or of $50 \%$ thereafter. In five of seven harvests obtained from non-CsA-treated piglets at $4 \mathrm{~d}$ or CsA-treated animals at 7-8 d after cardiac transplantation, there was either no or only a modest $(<150 \%)$ increase in fibronectin synthesis in donor compared to host coronary artery smooth muscle cells, whereas in six of seven harvests from non-CsAtreated piglets at 7-8 d or CsA-treated piglets at 10-31 d after cardiac transplantation, a $200-800 \%$ increase in fibronectin synthesis was observed $(P<0.05)$. 
Fibronectin $m R N A$ levels. We assessed fibronectin mRNA levels in smooth muscle cells from four different piglets where there was an increase in fibronectin protein synthesis in donor compared to host. Relative densitometry values for fibronectin mRNA in donor were $226 \pm 71 \%$ SE (range $104-400 \%$ ) of those in host when GAPD was used as the housekeeping gene and $242 \pm 50 \%$ SE (range $117-352 \%$ ) when ribosomal RNA was used to normalize for RNA loading conditions. In the individual animals, the magnitude of the increase in donor fibronectin mRNA levels was similar to the increase in fibronectin protein synthesis. Fig. 4 shows a representative Northern blot.

Identification of the cytokine regulating the increased fibronectin synthesis. We next carried out screening studies to determine whether cytokines known to be involved in the regulation of fibronectin synthesis and important in the immune-inflammatory reaction in allograft transplantation may be mediating the response observed. In these and all subsequent experiments, only cell harvests showing an increase in donor compared to host fibronectin synthesis were studied. The concentration of TGF- $\beta$ antibody used was based on the doses which neutralized $80 \%$ of $\left[{ }^{3} \mathrm{H}\right]$ thymidine incorporation in lung epithelial cells ( R \& D Systems) and also neutralized increased extracellular matrix production by endothelial cells in other studies carried out in our laboratory (23). The concentrations used of IL- $1 \alpha$ and IL- $1 \beta$ gave $90 \%$ inhibition of $1.2 \mathrm{ng} / \mathrm{ml}$ porcine IL- $1 \alpha$ and $84 \%$ inhibition of $2.5 \mathrm{ng} / \mathrm{ml}$ porcine IL- $1 \beta$ induced proliferation of chondrocytes and fibroblasts (41). The concentration used of IL- 6 antibody was in excess of the dilution used to block increased fibronectin synthesis by aortic endothelial and smooth muscle cells induced in co-culture experiments with monocytes (24).

In host coronary artery smooth muscle cells studied from three or four different harvests, we found no significant differences in fibronectin synthesis in the presence of neutralizing antibodies to TGF- $\beta$, IL- $1 \alpha$, IL- 6 , or IL- $1 \beta$ (Fig. $5 A$ ). This was also the case in the donor coronary artery smooth muscle cells in experiments with TGF- $\beta$, IL- $1 \alpha$, and IL-6 (Fig. $5 B$ ), but not

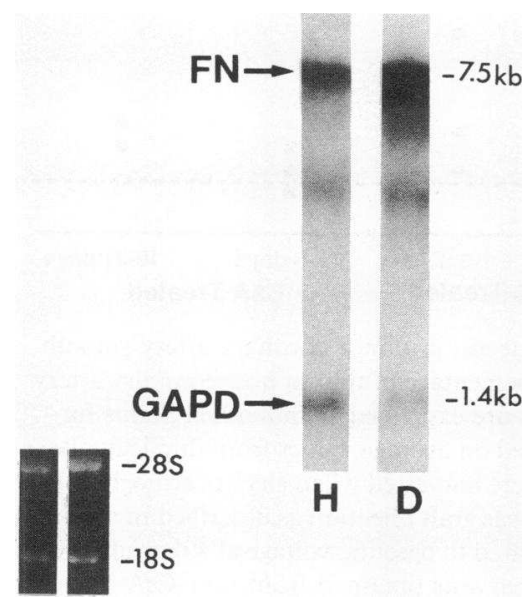

Figure 4. Representative Northern blot using RNA extracted from host and donor coronary artery smooth muscle cells from a CsA-treated piglet $10 \mathrm{~d}$ after transplant to assess mRNA levels for fibronectin. For a given amount of RNA loaded in the gel as assessed by hybridization with a GAPD cDNA, or by ribosomal RNA, there is increased intensity of hybridization using the fibronectin $(F N)$ cDNA

in the donor $(D)$ compared to host $(H)$ cells. The values for relative densitometry in donor compared with host using FN/GAPD were 10.46 compared with 2.61 , i.e., donor values are $400 \%$ of the host values, whereas densitometric data normalized for ribosomal ( $18 \mathrm{~s}$ and 28s) RNA were 44 versus 15 , i.e., donor values are $290 \%$ of the host values.
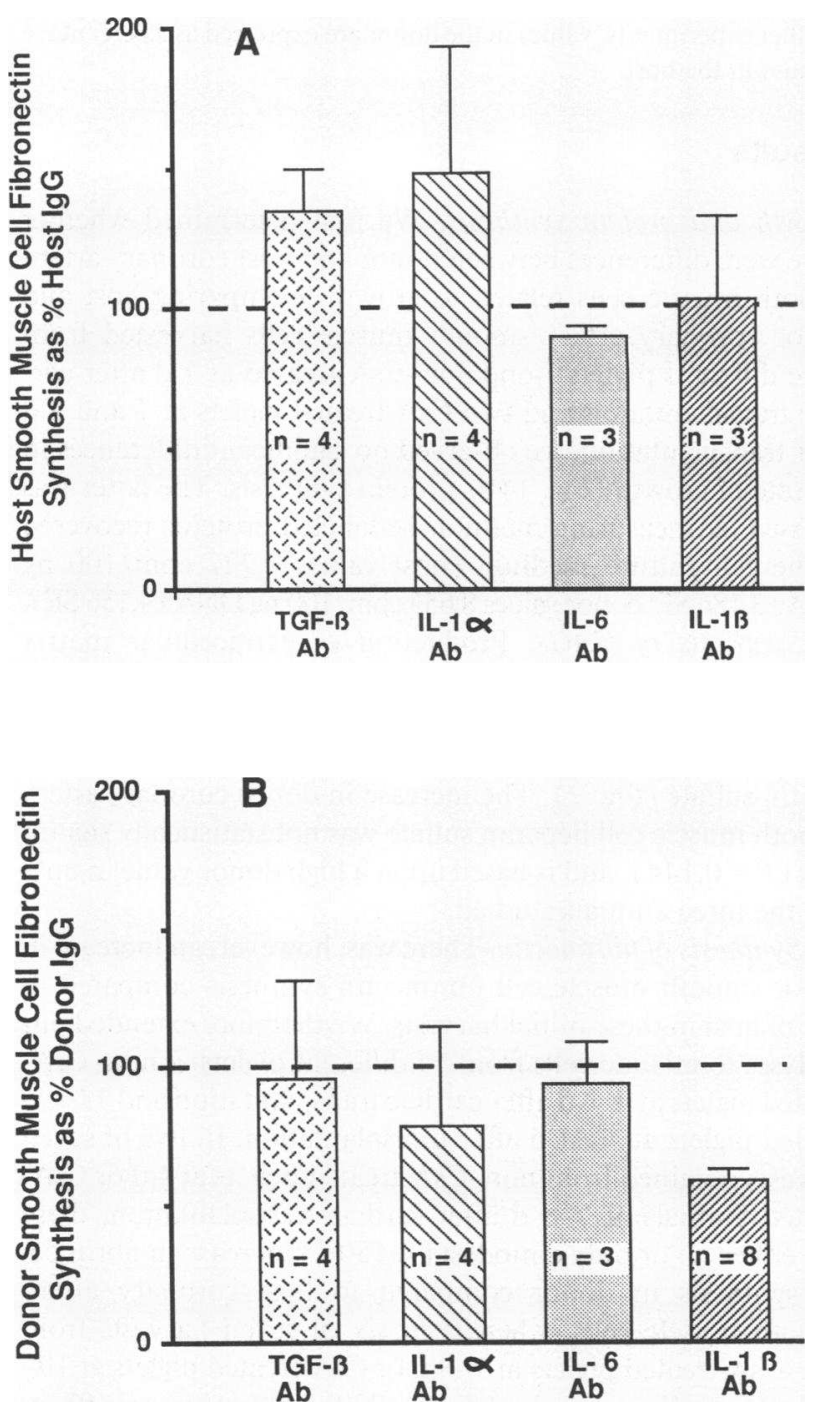

Figure 5. $(A)$ Fibronectin synthesis in host coronary artery smooth muscle cells in the presence of neutralizing antibodies $(A b)$ to TGF- $\beta$, IL- $1 \alpha$, IL- 6 , and IL- $1 \beta$ expressed as a percentage of control values (host samples using IgG). Values are expressed as mean \pm SE, based on average values from duplicate flasks. The number of different piglet cell harvests studied is indicated. The host coronary artery smooth muscle cells to which we added TGF- $\beta$ and IL- $1 \alpha$ antibodies were harvested from untreated piglets at 4 and $7 \mathrm{~d}$ and CsA-treated piglets at 7 and $10 \mathrm{~d}$ after transplant. The three host smooth muscle cell harvests to which we added IL- 6 and IL- $1 \beta$ neutralizing antibodies were from untreated piglets at 4 and $7 \mathrm{~d}$ and CsA-treated piglets at $7 \mathrm{~d}$ after transplant. There is no modulation of fibronectin synthesis by the cytokines screened. $(B)$ Fibronectin synthesis in donor coronary artery smooth muscle cells in the presence of neutralizing antibodies to TGF- $\beta$, IL- $1 \alpha$, IL- 6 , and IL- $1 \beta$ expressed as a percentage of control values (donor samples using IgG). Values are expressed as mean $\pm \mathrm{SE}$, based on average values from duplicate flasks. There is no significant modulation of donor fibronectin synthesis by TGF- $\beta$, IL- $1 \alpha$, and IL-6. The donor smooth muscle cell harvests were from the same animals indicated in $A$ as sources of host cells. The presence of IL- $1 \beta$ neutralizing antibodies, however, induces an approximate $40 \%$ reduction in donor fibronectin synthesis compared to values in control (untreated) cultures. The eight donor cell harvests used for IL- $1 \beta$ neutralization, were from two untreated piglets at $7 \mathrm{~d}$ and one at $4 \mathrm{~d}$ and two CsA-treated piglets at $7 \mathrm{~d}$ and three at $10 \mathrm{~d}$ after transplant. 
with IL- $1 \beta$. The use of the neutralizing antibody to IL- $1 \beta$ consistently reduced donor coronary artery smooth muscle cell fibronectin synthesis even when we extended these analyses to include cells from eight different piglets (mean $58 \pm 4 \% \mathrm{SE}$ ). Fibronectin synthesis in host compared to donor coronary artery smooth muscle cells in the same group of piglets showed a similar $56 \pm 12 \% \mathrm{SE}$ reduction. This suggested that endogenous IL- $1 \beta$ could account for the increased fibronectin synthesis in donor relative to host cells. The decrease in fibronectin synthesis in donor cells in the presence of IL- $1 \beta$ neutralizing antibodies was not associated with a generalized decrease in protein synthesis. In fact, in the donor coronary artery smooth muscle cells from six piglets assessed, values for total protein synthesis recovered in the cell culture medium in the presence of IL-1 $\beta$ antibodies were $175 \pm 12.4 \%$ SE of those in untreated cells.

Experiments with the $I L-1$ receptor antagonist. To further establish that IL- $1 \beta$ might be mediating the increase in donor coronary artery smooth muscle cell fibronectin synthesis, we repeated the above experiments using the IL-1 receptor antagonist ( ra) from $R$ \& D Systems in cells from three different harvests. Cultured smooth muscle cells were incubated for $24 \mathrm{~h}$ with IL-1 ra in a dose range of $1-100 \mathrm{ng} / \mathrm{ml}$ and fibronectin was extracted as described above. We also measured total proteins synthesized and secreted in the cultured medium (as described above) to assess whether changes in fibronectin were related to changes in total protein synthesis. Normal rabbit IgG was used as a control.

With increasing doses of the IL-ra, we observed a progressive reduction in donor coronary artery smooth muscle cell fibronectin synthesis. Fig. 6 shows a representative autoradiograph. Host coronary artery smooth muscle cell fibronectin synthesis (when normalized for DNA), was not significantly

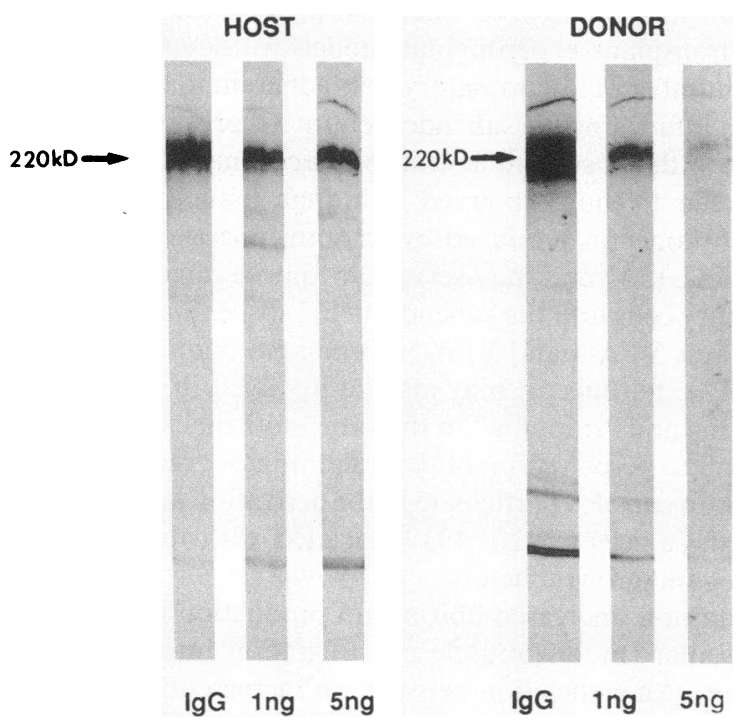

Figure 6. Representative autoradiograph of $5 \%$ SDS-PAGE after Gelatin $4 \beta$-Sepharose extraction to determine fibronectin synthesis in host and donor coronary artery smooth muscle cells (harvested from a CsA-treated piglet at $10 \mathrm{~d}$ after transplant) in the presence and absence of IL-1 ra. The apparent reduction in the host cell fibronectin synthesis at $5 \mathrm{ng} / \mathrm{ml}$ was not confirmed when the values were normalized by cell DNA content (data not shown). A progressive reduction in fibronectin synthesis is observed in the donor cells at 1 and $5 \mathrm{ng} / \mathrm{ml}$ of IL-1 ra. reduced by the IL-1 ra. The reduction in donor coronary artery smooth muscle cell fibronectin synthesis in the presence of the IL-1 ra was not associated with a reduction in total protein synthesis as judged by values in two different experiments which ranged from $82 \%$ to $121 \%$ at $10 \mathrm{ng} / \mathrm{ml}$ and from $170 \%$ to $194 \%$ at $20 \mathrm{ng} / \mathrm{ml}$ of those in untreated cells.

Addition of Exogenous $I L-1 \beta$. To confirm that coronary artery smooth muscle cells can respond to IL- $1 \beta$ by an increase in fibronectin synthesis, increasing doses of human recombinant IL- $1 \beta$ from 0.1 to $100 \mathrm{ng} / \mathrm{ml}$ (a gift from Dr. Nigel Staite, The Upjohn Co., Kalamazoo, MI) were added to the host cells in serum-free medium. The results were consistent in cells from all three different piglets studied, showing an increase in fibronectin synthesis in the presence of exogenous IL- $1 \beta$, at a concentration between 0.5 and of $20 \mathrm{ng} / \mathrm{ml}(P<0.02)$ (Fig. 7).

$I L-1 \beta$ and fibronectin $m R N A$ levels. Because the increase in donor compared to host fibronectin synthesis was accompanied by an increase in mRNA levels for fibronectin, we assessed whether the effect of the neutralizing IL- $1 \beta$ antibody was to reduce fibronectin mRNA as well as protein. In the cells from three different piglets assessed that we observed by relative densitometry, mRNA values in the IL- $1 \beta$ antibody-treated samples were reduced by $43 \pm 3.3 \%$ SE (range $36-47 \%$ ) compared to control samples treated with rabbit IgG, as judged by using GAPD as the housekeeping gene, and by $41 \pm 18 \%$ SE (range $22-77 \%$ ) normalizing by ribosomal RNA, and this correlated with the reduction in protein synthesis observed. Fig. 8 shows a representative Northern blot.

$I L-1 \beta$ synthesis. Once we documented that endogenous IL$1 \beta$ upregulates fibronectin synthesis in donor smooth muscle cells, we determined whether IL- $1 \beta$ synthesis was increased in these cells. In cells from three different harvests from CsAtreated piglets at $10 \mathrm{~d}$ after cardiac transplantation in which an increase in donor versus host fibronectin synthesis was initially

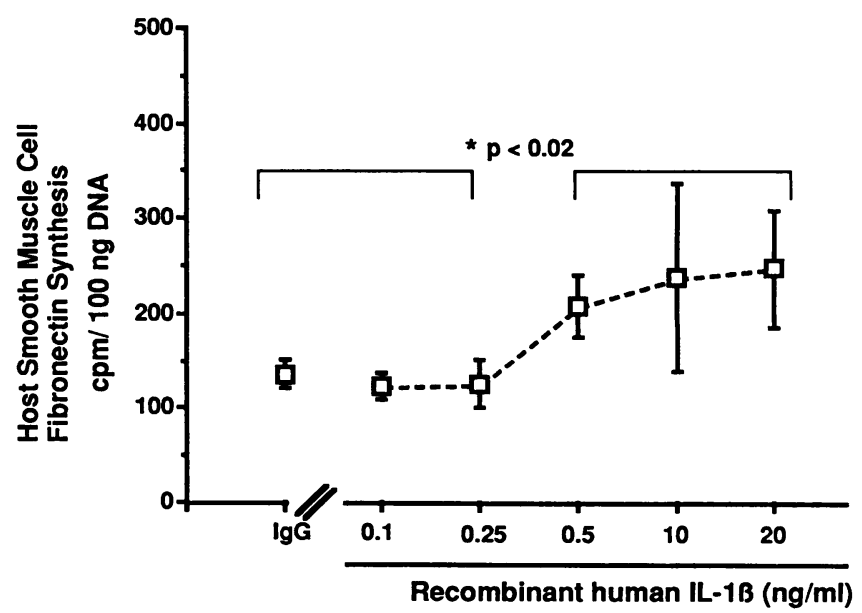

Figure 7. Dose-response curve of host coronary artery smooth muscle cell fibronectin synthesis to increasing doses of human recombinant IL-1 $\beta$. After labelling host smooth muscle cells from three different piglets with $\left[{ }^{35} \mathrm{~S}\right]$ methionine in the presence of increasing doses of exogenous IL- $1 \beta$ for $24 \mathrm{~h}$ an increase in newly synthesized fibronectin secreted in the cell culture medium is observed, between 0.5 and 20 $\mathrm{ng} / \mathrm{ml}$. Values shown represent mean \pm SEM. A difference is observed comparing the nine values under control, 0.1 and $0.25 \mathrm{ng} / \mathrm{ml} \mathrm{IL-1} \beta$ with the nine values between 0.5 and $20 \mathrm{ng} / \mathrm{ml},(P<0.02)$. 


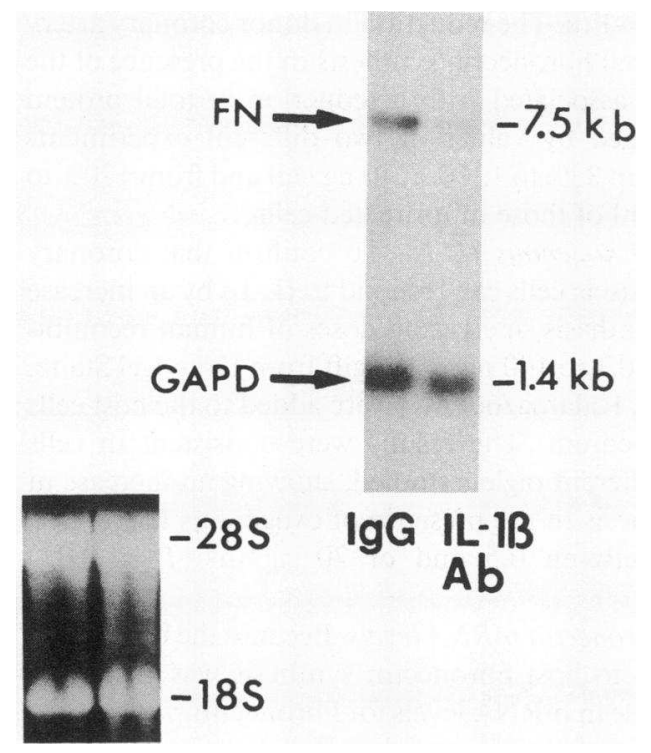

Figure 8. Representative northern blot of mRNA levels for fibronectin comparing IgG-treated donor samples treated with the neutralizing IL- $1 \beta$ antibody $(A b)$. Cells were obtained from a CsA-treated piglet $10 \mathrm{~d}$ after transplant. For amounts of RNA loaded in the gels as assessed by GAPD expression or ribosomal (18S and 28S) RNA, a reduction of fibronectin $(F N)$ mRNA levels is observed in the presence of IL- $1 \beta$ antisera. Using GAPD as the housekeeping gene, FN mRNA levels assessed by relative densitometry were 0.57 in the donor IgG-treated samples versus 0.37 in the IL-1 $\beta$-treated sample and this represented a $36 \%$ reduction whereas FN mRNA levels normalized for 18s RNA were 1.19 in the untreated and 0.93 in the IL- $1 \beta$ treated sample and this represented a $22 \%$ decrease.

observed, we immunoprecipitated newly synthesized IL-1 $\beta$. We confirmed that donor coronary artery smooth muscle cells produce more IL-1 $\beta$ than host cells (mean $150 \%$, range $125-$ $208 \%)$.

\section{Discussion}

In this study, we cultured donor and host coronary artery smooth muscle cells from piglets after heterotopic cardiac transplantation and found that there was an increase in fibronectin synthesis in the majority of donor cultures, especially with increasing duration after the cardiac transplant. Moreover, the increase in fibronectin synthesis appeared to be regulated by increased production of IL- $1 \beta$. These changes in cultured smooth muscle cells reflected the increased immunostaining for fibronectin and IL- $1 \beta$ observed in vivo in intact vessels (28), but we were able for the first time, through the in vitro studies, to establish a cause and effect relationship. These changes were rather specific in that the smooth muscle cells derived from host and donor coronary arteries were similar in phenotype, growth pattern, and protein synthesis. Although we cannot exclude that IL- $1 \beta$ may have affected expression of other molecules, by further showing that GAG synthesis from host and donor coronary artery smooth muscle cells were similar, it seemed that the increase in fibronectin did not reflect an increase in other extracellular matrix components that have previously been shown to be induced by IL-1 $\beta$ (18).
In our in vivo studies, (28), we could not relate the intensity of immunostaining for fibronectin to the duration after cardiac transplant in the presence and absence of CsA therapy, which differs from our observations in vitro, in which a correlation was apparent. This may reflect the fact that in vivo there is initial paracrine stimulation of fibronectin synthesis, likely by IL- $1 \beta$, which switches to an autocrine mechanism with increasing duration after the transplant, a process which may be accelerated in non-CsA-treated piglets. The paracrine source of IL$1 \beta$ may be the endothelial cells or the inflammatory cells. In fact, there appears to be intense immunostaining for IL-1 $\beta$ in the endothelium of the donor coronary arteries and our in vitro studies have confirmed increased synthesis of IL- $\beta$ in cultured donor compared to host endothelial cells (42). This explanation would be in keeping with previous reports in the literature suggesting that IL-1 upregulates itself (43). If the switch to an autocrine mechanism of IL-1 $\beta$-induced increased smooth muscle fibronectin is accelerated in the absence of cyclosporine, but requires a certain duration of expression to be maintained in vitro, this would explain why the donor smooth muscle cell cultures that were harvested at later time points in both treated and untreated animals were those that showed the consistent increase in fibronectin synthesis.

The increase in donor fibronectin synthesis was associated with increased steady-state mRNA levels for fibronectin. This feature differs from our studies in the ductus arteriosus where mRNA did not correlate with protein levels and a post-transcriptional mechanism appears to account for the increase in fibronectin synthesis (23). The difference may reflect the fact that the increase in ductus arteriosus fibronectin synthesis is related to a developmentally regulated program associated with morphogenesis, whereas the increase in the donor coronary artery is cytokine-mediated.

In our previous in vivo studies in piglets after heterotopic cardiac transplant experimental model, we described an increased number of inflammatory cells adherent to the endothelium and infiltrating the subendothelium as early features associated with the post-cardiac transplant coronary arteriopathy (28) similar to those observed in human tissue (4). The increased fibronectin produced by smooth muscle cells may be chemotactic (44) and may serve to promote migration of inflammatory cells into the subendothelial space. Inasmuch as $T$ cells express VLA-4 and VLA-5 fibronectin binding sites (10, $11,45-47$ ), fibronectin may also be involved in lymphocyte positioning and "trapping" in the subendothelial space, which could lead to perpetuation of the inflammatory reaction (48). Fibronectin can also participate in the activation and proliferation of these cells $(9,10,49)$ associated with the release of cytokines and growth factors.

In addition, increased fibronectin production is associated with vascular smooth muscle cell migration into the subendothelium. An association between an increase in fibronectin (5), particularly the EIII $\mathrm{A}^{+}$isoform (6) which is expressed by migrating cells $(50)$, and atherogenesis was previously reported. Moreover, in our earlier studies, we were able to show using three-dimensional collagen gels ( 51 ) and, more recently, using elastic membranes (52) that the increase in ductus arteriosus smooth muscle cell fibronectin synthesis is related to the cells' increased ability to migrate. This feature is related to the formation in vivo of intimal cushions, which partially narrow the lumen and assure that the vessel will close completely when 
it constricts in the postnatal period. Whereas others have also related fibronectin ( 53) or IL-1 (54) to proliferation of smooth muscle cells, we could not demonstrate this effect in our studies since we did not find differences in growth rate between host and donor cells.

Although we demonstrated increased immunostaining for IL- $1 \beta$ in the donor coronary artery tissue in the piglets (28), other cytokines can also mediate increased fibronectin synthesis, e.g., TGF- $\beta$, IL- $1 \alpha$, and IL-6 $(21,24)$. TGF- $\beta$ is known to stimulate synthesis of extracellular matrix during inflammatory reactions (22), and increased expression of IL-6, IL- $1 \alpha$, and IL- $1 \beta$ has been described in cardiac allografts (13). Moreover, Navab et al., in a co-culture system of smooth muscle cells, monocytes, and endothelial cells, demonstrated a decrease in fibronectin synthesis using both IL-1 and also IL-6 neutralizing antibodies (24). We therefore used neutralizing antibodies to TGF- $\beta$, IL- $1 \alpha$, IL- 6 , and IL- $1 \beta$ to screen for inhibition of fibronectin synthesis in the donor compared to host coronary artery smooth muscle cells and found that only IL- $1 \beta$ consistently and selectively reduced fibronectin synthesis in donor coronary artery smooth muscle cells. To further support the specificity of the effect observed with the IL- $1 \beta$ neutralizing antibody, we demonstrated a similar consistent reduction in donor coronary artery smooth muscle cell fibronectin synthesis with the IL-1 ra. We also established that both the IL- $1 \beta$ antibody and IL-1 ra effects on fibronectin synthesis were not part of a nonspecific downregulation of protein synthesis.

In that the increase in donor compared to host fibronectin synthesis is associated with an increase in mRNA levels for fibronectin, it is not surprising that the reduction in donor fibronectin synthesis with the IL- $1 \beta$ antiserum is associated with a decrease in mRNA levels for fibronectin. Further studies could be directed to explore whether this reflects differences in fibronectin mRNA stability or transcription.

The IL- $1 \beta$-mediated increase in fibronectin synthesis was associated with increased production of this cytokine by smooth muscle cells, thus providing further evidence for an autocrine mechanism. Since we also showed that exogenous IL- $1 \beta$ could stimulate smooth muscle cell fibronectin synthesis, we cannot exclude the possibility that initially in vivo, the stimulation is paracrine, the source being endothelial or inflammatory cell followed by an autocrine upregulation (43). We propose that this mechanism is responsible for the sustained increase in fibronectin synthesis and maintenance of this phenotypic characteristic in vitro.

Because the IL-1 ra has been effectively used therapeutically in the prevention of septic shock (55), and in the reduction of the inflammatory process in acute arthritis and colitis (56), this reagent could be used in vivo in experimental animals to establish more definitively whether the IL- $1 \beta$-mediated increase in fibronectin synthesis is critical to the pathogenesis of the post-cardiac transplant coronary arteriopathy. It would also be interesting to direct future studies toward the isolation of a responsive element for IL- $1 \beta$ in the fibronectin promoter. This may allow more selective therapeutic targeting of this effect without interfering with the other functions of IL- $1 \beta$.

\section{Acknowledgments}

The authors are thankful to Dr. John Coles and his group (Dr. Roberto Diaz and Ms. Jill Waddell) for performing the piglet cardiac trans- plants. We also thank Dr. Silvana Molossi for helping with the cell culture work. We are grateful to Joan Jowlabar for the graphic art work and Susy Taylor for secretarial assistance.

This study was supported by the Medical Research Council, Grant MT8546. Dr. Clausell is supported by Coordenadoria de Aperfeiçoamento para o Ensino Superior (CAPES), Brazil. Dr. Rabinovitch is a Career Investigator of the Heart and Stroke Foundation of Ontario.

\section{References}

1. Bieber, C., S. Hunt, D. Schwinn, S. Jamieson, B. Reitz, P. Oyer, N. Schumway, and E. Stinson. 1981. Complications in long-term survivors of cardiac transplantation. Transplant. Proc. 13:207-211.

2. Jamieson, S. W., P. E. Oyer, B. A. Reitz, W. A. Baumgartner, C. P. Bieber, E. B. Stinson, and N. E. Shumway. 1981. Cardiac transplantation: the Stanford experience. J. Heart Transplant. 1:86-91.

3. Uretsky, B. F., S. Murali, P. S. Reddy, B. Rabin, A. Lee, B. P. Griffith, R. L. Hardesty, A. Trento, and H. T. Bahnson. 1987. Development of coronary artery disease in cardiac transplant patients receiving immunosuppressive therapy with cyclosporine and prednisone. Circulation. 76:827-834.

4. Salomon, R., C. Hughes, F. Schoen, D. Payne, J. Pober, and P. Libby. 1991. Human coronary transplantation-associated arteriosclerosis. Am. J. Pathol 138:791-798.

5. Shekhonin, B. V., S. P. Domogatsky, G. L. Idelson, V. E. Koteliansky, and V. S. Rukosuev. 1987. Relative distribution of fibronectin and type I, III, IV, V collagens in normal and atherosclerotic intima of human arteries. Atherosclerosis. 67:9-16.

6. Glukhova, M., M. Frid, B. Shekhonin, T. Vasilevskaya, J. Grunwals, M. Saginati, and V. Koteliansky. 1989. Expression of extra domain A fibronectin sequence in vascular smooth muscle cells is phenotype dependent. J. Cell Biol. 109:357-366.

7. Wight, T. 1989. Cell biology of arterial proteoglycans. Atherosclerosis. 9:120.

8. Boudreau, N., and M. Rabinovitch. 1991. Developmentally regulated changes in extracellular matrix in endothelial and smooth muscle cells in the ductus arteriosus may be related to intimal proliferation. Lab. Invest. 64:187199.

9. Shimizu, Y., G. Van Seventer, K. Horgan, and S. Shaw. 1990. Costimulation of proliferative responses of resting $\mathrm{CD}^{+} \mathrm{T}$ cells by the interaction of VLA-4 and VLA-5 with fibronectin or VLA-6 with laminin. J. Immunol. 145:59-67.

10. Matsuyama, T., A. Yamada, J. Kay, K. Yamada, S. Akiyama, S. Schlossman, and C. Morimoto. 1989. Activation of CD4 Cells by fibronectin and antiCD3 antibody: a synergistic effect mediated by the VLA-5 fibronectin receptor complex. J. Exp. Med. 170:1133-1148.

11. Ager, A., and M. Humphries. 1991. Use of synthetic peptides to probe lymphocyte-high endothelial cell interactions. Lymphocytes recognize a ligand on the endothelial surface which contains the CS1 adhesion motif. Int. Immunol. 2:921-928.

12. Maury, C., and A.-M. Teppo. 1988. Serum immunoreactive interleukin 1 in renal transplant recipients. Transplantation. 45:143-147.

13. Leavy, J., C. Marboe, M. Barr, E. Rose, J. Brett, and D. Stern. 1991. Myocardial interleukin-6: A marker for accelerated graft atherosclerosis following cardiac transplantation. Circulation. 84:II-1935 (Abstr.).

14. Dallman, M., and G. Clark. 1991. Cytokines and their receptors in transplantation. Curr. Opin. Immunol. 3:729-734.

15. Moyer, C., D. Sajuthi, H. Tulli, and J. Williams. 1991. Synthesis of IL-1 alpha and IL-1 beta by arterial cells in atherosclerosis. Am. J. Pathol. 138:951960.

16. Libby, P., S. Warner, and G. Friedman. 1988. Interleukin 1: a mitogen for human vascular smooth muscle cells that induces the release of growth-inhibitory prostanoids. J. Clin. Invest. 81:487-498.

17. Kuijpers, T., B. Hakkert, M. Hoogerwerf, J. Leeuwenberg, and D. Roos. 1991. Role of endothelial leukocyte adhesion molecule-1 and platelet-activating factor in neutrophil adherence to IL-1-prestimulated endothelial cells. J. Immunol. 147:1369-1376.

18. Postlethwaite, A., G. Smith Jr, L. Lachman, R. Endres, H. Poppleton, K. Hasty, J. Seyer, and A. Kang. 1989. Stimulation of glycosaminoglycan synthesis in cultured human dermal fibroblasts by interleukin 1. J. Clin. Invest. 83:629636.

19. Warner, S., K. Auger, and P. Libby. 1987. Human interleukin-1 induces interleukin-1 gene expression in human vascular smooth muscle cells. $J$. Exp. Med. 165:1316-1331.

20. Shingu, M., M. Nobunaga, I. Ezaki, and K. Yoshioka. 1991. Recombinant human IL- $1 \beta$ and TNF- $\alpha$ stimulate production of IL- $\alpha$ and IL- $1 \beta$ by vascular smooth muscle cells and IL- $1 \alpha$ by vascular endothelial cells. Life Sci. 49:241246. 
21. Ignotz, R., T. Endo, and J. Massague. 1987. Regulation of fibronectin and type I collagen mRNA levels by transforming growth factor- $\beta$. J. Biol. Chem. 262:6443-6446.

22. Rizzino, A. 1988. Transforming growth factor-beta: Multiple effects on cell differentiation and extracellular matrices. Dev. Biol. 130:411-422.

23. Boudreau, N., N. Clausell, J. Boyle, and M. Rabinovitch. 1992. Transforming growth factor- $\beta$ regulates increased ductus arteriosus endothelial glycosaminoglycan synthesis and a post-transcriptional mechanism controls increased smooth muscle fibronectin, features associated with intimal proliferation. Lab. Invest. 63:350-359.

24. Navab, M., F. Liao, G. Hough, L. Ross, B. Lenten, T. Rajavashisth, A. Lusis, H. Laks, D. Drinkwater, and A. Fogelman. 1991. Interaction of monocytes with cocultures of human aortic wall cells involves interleukins 1 and 6 with marked increases in connexin 43 message. J. Clin. Invest. 87:1763-1772.

25. Muller, D., S. Ellis, and E. Topol. 1992. Experimental models of coronary artery restenosis. J. Am. Coll. Cardiol. 19:418-432.

26. Kirkman, R., R. Colvin, and W. Flye. 1979. Transplantation in miniature swine VI: factors influencing survival of renal allografts. Transplantation. 28:1823.

27. Pescovitz, M., J. Thistlethwaite, and H. Auchincloss. 1984. Effect of class II antigen mismatching on renal allograft survival in miniature swine. $J$. Exp. Med. 160:1495-1508.

28. Clausell, N., S. Molossi, and M. Rabinovitch. 1993. Increased interleukin$1 \beta$ and fibronectin expression are early features of the development of the postcardiac transplant coronary arteriopathy in piglets. Am. J. Pathol. 142:17721786.

29. Dasmahapatra, H., G. Wilson, S. David, S. Kielmanowicz, G. Kent, S. Gokhale, A. Shore, and J. Coles. 1988. A new technique of experimental heterotopic cardiac transplantation. Cardiovasc. Res. 22:296-299.

30. Koike, K., P. Hesslein, H. Dasmahapatra, G. Wilson, C. Finlay, S. David, S. Kielmanowicz, and J. Coles. 1988. Telemetric detection of cardiac allograft rejection. Correlation of electrophysiological, histological, and biochemical changes during unmodified rejection. Circulation. 78(Suppl. I):I106-I112.

31. Ross, R. 1971. The smooth muscle cell. II. Growth of smooth muscle in culture and formation of elastic fibers. J. Cell Biol. 50:172-186.

32. Gown, A., T. Tsukada, and R. Ross. 1986. Human atherosclerosis. II. Immunocytochemical analysis of the cellular composition of human atherosclerotic lesions. Am. J. Pathol. 125:191-207.

33. Rabinovitch, M., S. Beharry, T. Bothwell, and G. Jackowski. 1988. Quantitative and quantitative differences in protein synthesis comparing fetal lamb ductus arteriosus endothelium and smooth muscle with cells from adjacent vascular sites. Dev. Biol. 130:250-258.

34. DiCorleto, P., and D. Bowen-Pope. 1983. Cultured endothelial cells produce a platelet-derived growth factor like protein. Proc. Natl. Acad. Sci. USA. 80:1919-1923.

35. Kramer, R., G. Fuh, K. Bensch, and M. Karasek. 1985. Synthesis of extracellular matrix glycoproteins by cultured microvascular endothelial cells isolated from dermis of neonatal and adult skin. J. Cell. Physiol. 123:1-9.

36. Copp, A., and M. Bernfield. 1988. Basement membrane-associated hyaluronate accumulation is reduced in the posterior neuropore region of mutant mouse embryos developing spinal neural tube defects. Dev. Biol. 130:583-590.

37. Lee, Y., B. Radhakrishnamurthy, E. Delfres, and G. Berenson. 1987. Determination of aorta glycosaminoglycans by high performance liquid chromatography. J. Chromatogr. 419:275-279.

38. Wrana, J., M. Maeno, B. Hawrylyshyn, K. Yao, C. Domenicucci, and J. Sodek. 1988. Differential effects of transforming growth factor beta on the synthe- sis of extracellular matrix proteins by normal fetal rat calvarial bone cell population. J. Cell Biol. 106:915-924.

39. West, D., A. Sattar, and S. Kumar. 1985. A simplified in situ solubilization procedure for the determination of DNA and cell number in tissue cultured mammalian cells. Anal. Biochem. 147:289-295.

40. Chomczynski, P., and N. Sacchi. 1987. Single-step method of RNA isolation by acid guanidinium thiocyanate-chloroform extraction. Anal. Biochem. 162:156-159.

41. Saklatvala, J., S. Sarsfield, and Y. Townsend. 1985. Pig interleukin 1: purification of two immunologically different leukocyte proteins that cause cartilage resorption, lymphocyte activation and fever. J. Exp. Med. 162:1208-1222.

42. Molossi, S., N. Clausell, and M. Rabinovitch. 1993. Coronary artery endothelial interleukin- $\beta$ mediates enhanced fibronectin production related to postcardiac transplant arteriopathy in piglets. Circulation. In press.

43. Loppnow, H., and P. Libby. 1992. Functional significance of human vascular smooth muscle cell-derived interleukin 1 in paracrine and autocrine regulation pathways. Exp. Cell Res. 198:283-290.

44. Linask, K., and J. Lash. 1988. A role for fibronectin in the migration of avian precardiac cells. I. Dose-dependent effects of fibronectin antibody. Dev. Biol. 129:315-323.

45. Shimizu, Y., G. Van Seventer, K. Horgan, and S. Shaw. 1990. Roles of adhesion molecules in T-cell recognition: fundamental similarities between four integrins on resting human T cells (LFA-1, VLA-4, VLA-5, VLA-6) in expression, binding and costimulation. Immunol. Rev. 114:109-142.

46. Li, Y., and H. Cheung. 1992. Basement membrane and its components on lymphocyte adhesion, migration and proliferation. J. Immunol 149:3174-3181.

47. Mobley, J., and M. Dailey. 1992. Regulation of adhesion molecule expression by CD8 T cells in vivo. I. Differential regulation of $\mathrm{gp} 90^{\mathrm{MEL}-14}$ ( LECAM-1) Pgp-1, LFA-1, and VLA-4 $\alpha$ during the differentiation of cytotoxic $T$ lymphocytes induced by allografts. J. Immunol. 148:2348-2356.

48. de Sousa, M., N. Tilney, and J. Kupiec-Weglinski. 1991. Recognition of self within self: specific lymphocyte positioning and the extracellular matrix. Immunol. Today. 12:262-266.

49. van Seventer, G., Y. Shimizu, and S. Shaw. 1991. Roles of multiple accessory molecules in T-cell activation. Curr. Opin. Immunol. 3:294-303.

50. French-Constant, C., and R. Hynes. 1988. Patterns of fibronectin gene expression and splicing during cell migration in chicken embryos. Development. 104:369-382

51. Boudreau, N., E. Turley, and M. Rabinovitch. 1991. Fibronectin, hyaluronan and a hyaluronan binding protein contribute to increased migration of ductus arteriosus smooth muscle cell. Dev. Biol. 143:235-247.

52. Hinek, A., J. Boyle, and M. Rabinovitch. 1992. Vascular smooth muscle cell detachment from elastin and migration through elastic laminae is promoted by chondroitin sulfate-induced "shedding" of the 67-kDa cell surface elastin binding protein. Exp. Cell Res. 203:344-353.

53. Hedin, U., B. Bottger, E. Forsberg, S. Johansson, and J. Thyberg. 1988. Diverse effects of fibronectin and laminin on phenotypic properties of cultured arterial smooth muscle cells. J. Cell Biol. 107:307-319.

54. Raines, E., S. Dower, and R. Ross. 1989. Interleukin-1 mitogenic activity for fibroblasts and smooth muscle cells is due to PDGF-AA. Science (Wash. DC) 243:393-396.

55. Ohlsson, K., P. Bjork, M. Bergenfeldt, R. Hageman, and R. Thompson. 1990. Interleukin-1 receptor antagonist reduces mortality from endotoxin shock Nature (Lond.). 348:550-552.

56. Arend, W. 1991. Interleukin 1 receptor antagonist. A new member of the interleukin 1 family. J. Clin. Invest. 88:1445-1451. 